\title{
Life Writing from Below in France
}

\author{
Nathalie Ponsard
}

Université Clermont Auvergne

\section{ABSTRACT IN ENGLISH}

Without seeking to be exhaustive, this paper offers an overview of the different ways in which workers' autobiographies have been analysed in France in the human sciences. In the first phase, a social and political approach was dominant. Through workers' autobiographies written in the nineteenth and twentieth centuries, researchers have attempted to grasp the relationship to politics, and especially in the twentieth century the acceptance or rejection of the communist model in the reconstruction of their political and trade union trajectories. At the same time, in a cultural approach, they have tried to understand the educational and literary influences which marked these self-taught workers who, unusually in the workers' world, crossed over from practices of reading to practices of writing. Over the last ten years, workers' autobiographies have become sources particularly used in the framework of labour history and workers' history. Indeed they make it possible to grasp how men and women articulate their working conditions: the atmosphere in the workshop, gestures in work and relations between the body and the work, perception of noises and smells, relationships with hierarchy and trade-unions. These autobiographies can be considered as constituting real "political acts" which contribute to class struggle. Finally, at the intersection of anthropological researches about "ordinary writings" and literary studies about the writing of work and writing at work, they pose a question about the means and the meaning of writing experiences by paying more attention to the form of the writings and to the workers' literary ambitions, which are often revealed in interviews.

\section{ABSTRACT IN FRENCH}

Sans viser l'exhaustivité, cet article offre un panorama des manières dont les autobiographies d'ouvriers et d'ouvrières ont été analysées en France dans le 
champ des sciences humaines. Dans un premier temps, l'approche sociale et politique a dominé. A travers les autobiographies ouvrières du XIX comme $\mathrm{du} \mathrm{XX}^{\mathrm{e}}$ siècle les chercheurs ont voulu cerner le rapport au politique et notamment au XX $\mathrm{XX}^{\mathrm{e}}$ siècle l'appropriation ou le rejet du modèle communiste. Ils ont donc été attentifs à la reconstitution des parcours politiques et syndicaux.

Parallèlement, dans une approche culturelle, ils ont tenté de comprendre la formation et les influences littéraires de ces ouvriers autodidactes qui, singuliers dans le monde ouvrier, sont passés de pratiques de lectures à des pratiques d'écritures. Depuis une dizaines d'années, les autobiographies ouvrières sont devenues des sources particulièrement utilisées dans le cadre d'une histoire du travail et des travailleurs. Elles permettent en effet de saisir comment des individus, hommes et femmes, disent leurs expériences du travail: ambiance d'atelier, gestes et rapports au corps, perception des bruits et des odeurs, relations hiérarchiques et syndicales. Elles peuvent être considérées comme de véritables actes politiques dans un contexte de lutte de classe. Enfin, à la croisée des recherches anthropologiques sur les écritures ordinaires et des recherches littéraires sur les écritures du travail et au travail, un questionnement s'est cristallisé sur les modalités et le sens de ces expériences d'écritures en prêtant davantage attention à la forme des écrits et aux ambitions littéraires des ouvriers, bien souvent révélées au cours d'entretiens oraux.

Keywords: life writing from below, France, political autobiographies, workers' literary writings, workers' identity, protest and emancipation

This article is one contribution towards a history of life writing from below on the European level. It focuses on workers' writings with the aim of highlighting some historical approaches towards these texts. In the nineteenth and twentieth centuries, life writings from below in France were very heterogeneous. Some were written by workmen-and rarely by women workers - who belonged to various occupational sectors (miner, metalworker...), others were written by craftsmen or peasants (Guillaumin; Roche). One may add ordinary life writing in the twentieth century where women were better portrayed (Fabre). One may also think about the flowering of autobiographies based on interviews transcribed by research professors or the autobiographies co-constructed by intellectuals and workers (Goux; Corouge and Pialoux). Indeed, since the sixties, the context has been favourable: a generalized possibility of speaking, the development of qualitative sociology (Bertaux), and the beginning of oral history (Descamps). But, in this article, I am going to focus on research about workers' autobiographies. Even if their number was less significant in the nineteenth century-especially by comparison with Britain, since 1945, in contrast, the number of autobiographies has been 
increasing and today they are used more and more in the new history of workers.

In France, there is no single catalogue which locates workers' autobiographies but several research tools and archives are valuable:

- The web site of Dictionnaire biographique du mouvement ouvrier français which was founded by Jean Maîtron. It includes an inventory of 400 titles for the nineteenth and twentieth centuries. Moreover a catalogue entitled Prosopography of militants 1940/1968 offers a bibliographical approach which distinguishes three types of writings: first published or unpublished autobiographies; secondly letters, notebooks, diaries; and thirdly collective testimonies collected by research professors, journalists, or militants. ${ }^{1}$

- Le centre d'histoire du travail ${ }^{2}$ (the centre for the history of labour) in Nantes, as well as the Bibliothèque de Documentation Internationale Contemporaine (BDIC) in Paris ${ }^{3}$, each holds a collection of autobiographies.

- Finally, in Ambérieu-en-Bugey near Lyon, the Association pour l'autobiographie et le patrimoine autobiographique (APA), created by Philippe Lejeune and Chantal Chaveyriat-Dumoulin in 1992, is an important place of preservation of the autobiographical heritage. ${ }^{4}$ Its holdings include 300 workers' autobiographies, registered with synopses in its online catalogue.

From the production of workers' autobiographies, ${ }^{5}$ even if other classifications are possible, one can propose a history of workers' autobiographies based on three generations:

1. Workers' autobiographies in the nineteenth century.

They were written by the workers' aristocracy who were self-taught people. They express a fight for citizenship and for emancipation against the domination of the ruling classes.

2. Autobiographies of militant workers, more or less in accordance with the communist pattern.

Since the sixties, politically militant workers have written their autobiographies to recount their trajectory. Some borrow the established communist pattern of model life-writings, others-ex-communists, Trotskyists, anarchists-have written dissident life-writings. In a context characterised by the communist crises, the end of the USSR as a pattern of a socialist country, and "the end of the working class," these two groups wished to leave behind them a record of their political struggles.

3. Critical autobiographies in the wave of contestation in the seventies. In the seventies, unskilled workers and women workers wrote in the process of emancipation. They fought the "factory order," 
especially the power of foremen and meaningless work in the production-line. They also fought the power of trade-unionism and the political order.

Thus these three generations of workers' autobiographies reveal the important moments of the workers' history in French society and in the French labour movement since the thirties dominated by the communist process.

However alongside this political classification, I aim to study how research professors have used these autobiographies from below: What were the significant trends? What are the current trends? In other words my approach is methodological and historiographical. First I analyse the uses of the workers' autobiographies in the human sciences, in political, social and cultural history. Then I set out more recent historical approaches undertaken within the current historiography of labour and of the workers. ${ }^{6}$

\section{I: USES OF WORKERS' AUTOBIOGRAPHIES IN THE HUMAN SCIENCES}

On the one hand, workers' autobiographies were studied in the field of social and political history based on socio-biographies and political paths; on the other hand, in the field of cultural history, the reading and writing practices of workers have been investigated to reveal the respective influences of literary culture or workers' culture.

\section{A Socio-Biographical Approach Marked by Politics}

Since the sixties in the new social history some research has been carried out into collective biographies, the first great characters of the labour movement and then the ordinary militants in the frame of a history from below (influenced by microhistory and sociology). ${ }^{7}$ So Michelle Perrot has approached the question of workers' autobiographies in the nineteenth century. Her paper was published in the great book Lieux de Mémoire edited by Pierre Nora (Perrot 1992). She emphasized several themes in these texts: the great place of the "la chose publique" deriving from the French Revolution in 1789 and a belief in a sense of historical destiny, as well as praise of work, of learning, and of the sciences. She brought to light the specific testimonial form used by the working class, which contrasts with the autobiographical pact defined by Philippe Lejeune. $^{8}$ 
The second approach came from Claude Pennetier and Bernard Pudal who offered us a methodological and epistemological contribution. Indeed they investigated the autobiographies of communist militants and leaders who came from proletarian communities. They insisted on the context of the writings, especially the analysis of the biographical device developed by the Soviet Communist Party since the twenties. So in the international communist movement, the workers who became leaders wrote their edifying autobiographies to glorify the USSR as the first socialist country or to condemn capitalist exploitation. In France the autobiography of Maurice Thorez, leader of the PCF from 1934 to 1964, entitled Fils du Peuple ("son of the people") set the pattern. It illustrated the worker militant's path and established the official history of the Communist Party. So from this pattern a classification was created; it makes it possible to distinguish: texts which are in accordance with this pattern; more distant autobiographies which show differences due to their author's degree of responsibilities within the party or to their being written at a time affected by the communist crisis; and finally critical autobiographies.

Claude Pennetier and Bernard Pudal's approach revealed a deep transformation: political autobiographies became intimate biographies which made it possible to understand the ties between writing practices and expression of intimate experience. In addition they invited researchers to determine the criteria defining the corpus of autobiographies. In their work, they decided that the corpus of texts they identified must: be published, evoke an autobiographical pact, and focalize their narrative on the communist commitment. So, in my view, if we want to construct a specific corpus of writings from below, we must also have a carefullydefined corpus to be able to compare the texts with each other.

Beyond this political approach, we must also note a valuable literary and cultural approach.

\section{Workers' Autobiographies and the Literary Approach}

\section{2a. Workers' autobiographies and the field of workers' literature}

At the beginning of the seventies, Michel Ragon wrote Histoire de la littérature prolétarienne de langue française. ${ }^{9}$ He wanted to make an inventory of the texts written by workers who were self-taught, had received a manual training, had remained in their original proletarian occupations, and who expressed the ideas and values of the popular world. He took up the challenge to restore this "unknown" literature which was marginalized by the canonical literary field and also rejected by the 
literary framework of the Communist Party. According to him, those writings would really show "le visage authentique du peuple, son évolution, ses aspirations, ses plaintes et ses joies" (the authentic figure of the people, its evolution, its aspirations, its complaints and its joys) (Ragon 1974, p. 19). However, since the beginning of the nineteenth century, the workers' writings were influenced by forms and ideologies which originated outside the proletarian milieu. They were marked by the songs of Pierre-Jean Béranger, a great popular cabaret singer. So they recapitulated the same themes (political satire against monarchy, anticlerical opposition, and glorification of people) and copied also the poetic form. They were influenced also by the Romantic movement, and ideas from the Saint-Simonian socialists such as emancipation, solidarity, exploitation (Thomas). So for the twentieth century, marked by mass culture, we must question the complete autonomy of the workers' literature and insist on the fact that it was hybrid and open to external literary influences.

This is confirmed by the sociologist Michel Verret. He explains that the worker writers are "unique figures in writing" ("des singuliers de l'écriture") both in the workers' world and in the literary field. According to him these worker writers have left their class because they have encountered intellectuals through their commitment.

\section{2b. Workers' Autobiographies and their Literary Culture}

However autobiographies not only express workers' culture, more precisely they allow us to reconstruct the literary culture of certain workers: we must study the approach of Martyn Lyons. This historian has reconstructed the workers' literary culture from twenty-two autobiographies of self-taught workers. For instance through the autobiography of Norbert Truquin he shows the stages of appropriation of learning: the importance of oral transmission, then the initial phase of eclectic readings and finally "the conversion of the bad reader." ${ }^{10}$ Lyons also shows that the commitment to writing occurs through poetry and autobiography. He gives an interesting typology: the spiritual autobiography (more important in Great Britain); the symbolic autobiography which demonstrates the history of the workers; and the autobiography of personal success. Beyond these types he insists on the fact that the autobiography contributes to constructing their identity even if the workers use narrative and stylistic forms which are encountered in their various readings. These autobiographies are emancipating.

At the present time the political and literary approaches to workers' autobiographies persist but there are also new uses in the field of the history of labour. 
II: MORE RECENT HISTORICAL APPROACHES:

AUTOBIOGRAPHIES AND THE HISTORY OF LABOUR AND OF THE WORKERS

For the last ten years, historians have been studying the relations between the individual, history and memory through narrative in order to question intimate being and social identity (Crivello and Pelen). They have focused their attention on the testimonies of lived experiences which are at the same time traces of a writing experience and testimonies for history (Jouhaud et al.).

\section{A Political and Literary Approach to Written Testimonies: Between the Singular and the Collective}

In his latest study, Xavier Vigna took up the challenge to analyse together writings from the working class and writings about the working class in a broad intertextual comparison. ${ }^{11}$ In the social and political world, the working class was central in France. For Vigna, the category of workers' writings is more diverse than it has often been defined: it includes autobiographies but also testimonies, surveys, fictions and militant accounts. This wide range of different writings from the working class, he argues, constituted a "political act" which contributed to class struggle. So those writings were forms of subjective politicization towards communist hegemony. At least they revealed the literary ambition in the workers' world which participated in an effort to change both the social identity of the working class, and the identities of individual worker writers themselves.

The thesis of Eliane Le Port deals with "workers' written testimonies," which put the experience of work and the working conditions at the core of their writing experience. Her work has three focuses: the authors (especially their education); the content of their texts (for example, the negative experience of trade-unionism); and writing practices, narrative and editorial forms (such as the insertion of "factory writings" in their testimonies). ${ }^{12}$ For Le Port those factory writings are political acts but also written traces of the workers' thinking. Therefore they inform us about the trajectories and values of the working world. They also allow the author to study the processes of writing through individual interviews which she also conducted with worker-writers. This leads to an understanding of how a worker made the transition from work to writing about work. In the frame of the history of writing practices, Le Port tries to understand this singular and solitary experience as well as the effects on the authors' social identity and the lived experience which is reconstructed. 


\section{Diaries Between Gender Identity and Social Class}

Historian of women workers Fanny Gallot, has investigated three diaries written at the beginning of the seventies in an interesting article. ${ }^{13}$ These diaries reveal the making of a female sociability to resist their working conditions. They give information about the difficulties for women to have commitments in the trade-unions. Gallot questions what is at stake in the writing of these diaries. Certainly these women have written in the first person but in fact these writings are collective. These are "manifestos" for the struggles of women workers. They show the legitimacy of their struggles and reveal the influence of feminist ideas (even if the word itself was not pronounced). So here too there is an emancipatory writing like those of workers in the nineteenth century.

\section{Workers' Writings and the Body at Work}

At the intersection of the history of work and the history of the body, the book written by Thierry Pillon, Le corps à l'ouvrage, is based on testimonies, life writings, workers' autobiographies. Through 50 texts, he investigates the expression of the relations between the body and the work. On the one hand, he shows how the place of work can be a form of captivity. He insists on the appropriation of the work in the body (the marks of the work on the body, the physical sufferings and also the professional illnesses). On the other hand, he explains that the body can be used to identify workers. So it reveals the physical performance and the resistance to pain which contribute to a recognition by their fellow workers. Finally, the work can stimulate different kinds of dreams which correspond to the technical evolution of the work. In other words, Pillon identifies three figures of dreams: an escape into images of nature which remained close to workers at the turn of the twentieth century; an escape into contemplation of materials and dexterity of gesture; an escape tied to repetitive work and the dream-like fatigue it provokes (Pillon 2011).

\section{Autobiography: Source for Biographical Construction}

The individual autobiography is also valuable as Michelle Perrot shows with her latest book Mélancolie ouvrière. Starting from a text by Lucie Beaud (1870-1913) entitled "Les tisseuses de soie dans la region de Vizille," Michelle Perrot depicts the working conditions of the women workers in the silk industry at the end of the nineteenth century. Using other sources as well, her purpose is to recount the path of this woman worker militant and to explain how she organized a strike movement.

In a similar fashion Christian Chevandier traces the path of a militant named Georges Valero (1937-1990). So he researches the intellectual 
and material conditions of Valero's writings. ${ }^{14}$ Thus, he tries to seek Valero's intentions through his letters and reveals the readings which inspired him. He analyses his books in comparison with proletarian literature. Especially, he tries to understand the intimate reasons of writing: at the beginning, writing was therapeutic to overcome the experience of war of Algeria; then, writing gives meaning to his life: Valero wanted to write about the humiliations of workers' lives but also their dignity. Chevandier concludes that Valero's writings are also emancipatory. Indeed he analyses the representation of his militant's daily life which is very different from the idealized representation of the militant in communist literature.

Finally, in my own work, I try to understand the transition of an individual and initial involvement as a political and trade-unionist to a wider cultural engagement through the career of a trade-union militant, the miner and metal-worker Jean-Claude Daffix (born 1937). To understand how and why a militant, shaped by trade-union writing, took up writing poetry. It is necessary to explore the meaning of writing which is at the same time a testimony of his identity, of his commitments, and of the culture of miners, while re-situating that experience of writing in a larger cultural field, so as to understand better cultural interactions (between popular culture, workers' culture, literary culture, mass culture). For instance I want to identify the appropriation of poetic patterns to build a social and personal poetry which is a form of life writing or a form of poetic testimony. ${ }^{15}$ In this perspective, it seems interesting to adopt the literary methodological approach which is expanding currently (Bikialo and Engélibert; Grenouillet).

This journey through workers' autobiographies in France reveals the wealth of these historical sources in helping us: to understand the workers' political culture but also their processes of emancipation and assertiveness; to grasp the relations between workers' culture and literary culture, and the types of appropriation of dominant culture which they made through their readings and writings; as well as to reconstruct workers' biographical trajectories. In many cases these autobiographies can be considered as valuable "written testimonies" for labour history. They are also political weapons which contribute to class struggle. Furthermore, they are writings which reveal literary work and workers' thinking, in other words, "a thinking in action."

Finally, to indicate directions for continuing the discussion, I would like to point out some elements for a study on the European level. First, we can think about the making of politico-literary spaces in the European workers' world. My working hypothesis is that this is facilitated by the circulation of patterns of writing across national borders ${ }^{16}$ but also through exchanges between exiled political militants. In any case we must take into account national or local specificities. 
- In the communist sphere, it would be judicious to compare the French worker autobiographies with Italian autobiographies but also with lifewriting of "writer workers" promoted by firms within the DDR. ${ }^{17}$ Perhaps we also must explore worker life-writings in Eastern Europe after the fall of the Berlin Wall.

- In the anarchist sphere, there are comparisons between French, Spanish and Italian autobiographies because anarcho-syndicalism dominated the workers movement in Southern Europe until the First World War.

- Finally, much of Europe experienced the rebellion of 68, the protest against line-production and the fashion of life-writings from below which occurred at the same time as the breakthrough of Italian "microstoria," and of oral history from below in England and Germany: did this context also induce the emergence of the "I" among the European unskilled workers?

- In other words, on the European scale, is there the issue of the singularity of the worker writer in the workers' world? Is there an issue of a double identity? Is the writer worker considered as a cultural "go-between"?

- Are European workers' life writings still and everywhere emancipatory?

\section{WORKS CITED}

\section{Archival sources}

“Journal d'un groupe d'ouvrières, Montpellier 1967-1968". Bibliothèque de Documentation Internationale Contemporaine, Paris, FdeltaRes578/14, 65 pages.

\section{Printed sources}

Beaud, Lucie. "Les tisseuses de soie dans la region de Vizille." Le Mouvement socialiste, juin 1908, 418-425; reprinted in Le Mouvement social, no. 105, Travaux de femmes dans la France du XIXe siècle (Oct.-Dec., 1978). 139-146.

Bertaux, Daniel. Le récit de vie. $2^{\circ}$ édition, Paris: Armand Colin, 2005.

Bikialo, Stéphane, and Jean-Paul Engélibert. Dire le travail. Fiction et témoignage depuis 1980, La Licorne: revue de langue et de littérature françaises (Presses Universitaires de Rennes) no. 103, 2012.

Chevandier, Christian. La Fabrique d'une génération. Georges Valero postier, militant et écrivain. Paris: Les Belles Lettres, 2009.

Corouge, Christian, and Michel Pialoux. Résister à la chaine. Dialogue entre un ouvrier de Peugeot et un sociologue. Marseille: Agone, 2011.

Crivello, Maryline, and Jean-Noël Pelen. Individu, récit, histoire. Aix-en-Provence: Publication de l'Université de Provence, 2008.

Descamps, Florence. L'historien, l'archiviste et le magnétophone: de la constitution de la source orale à son exploitation. Paris: Ministère de l'économie des finances et de l'industrie, Comité pour l'histoire économique et financière de la France, 2005.

Fabre, Daniel, (ed.). Écritures ordinaires. Bibliothèque publique d'information, Centre Georges Pompidou/P.O.L Editions, 1994. 
Gallot, Fanny. "Quelques journaux intimes d'ouvrières dans les années 1968: des manifestes?" In Littérature ouvrière, éditée par l'Association Ecomusée du Creusot-Montceau, Rencontres 2011. 39-48.

Goux, Jean-Paul. Mémoires de l'enclave. Arles: Actes Sud, 2003.

Grenouillet, Corinne. Usines en textes, écritures au travail. Témoigner du travail au tournant $d u$ XXIe siècle. Paris: Classiques Garnier, 2014.

Guillaumin, Emile. La Vie d'un simple. Paris: Editions Stock, 1943.

Jouhaud, Christian, Dinah Ribard and Nicolas Schapira. Histoire, littérature et témoignage: écrire les malheurs du temps. Paris: Gallimard, 2009.

[Lopez, Aurélie]. Aurélie, journal d'une OS [ouvrière spécialisée; unskilled worker]. Paris: Les Editions ouvrières, 1979.

Lyons, Martyn. "La culture littéraire des travailleurs. Autobiographies ouvrières dans l'Europe du XIXe siècle." Annales. Histoire, Sciences Sociales 4 (2001): 927-946.

Matériaux pour l'histoire de notre temps. Special issue "Le mouvement ouvrier au miroir de la biographie." Nos. 104-105 (2011).

Pennetier, Claude et Pudal, Bernard. Autobiographies, autocritiques, aveux dans le monde communiste. Paris, Belin, 2002.

Perrot, Michelle. "Les vies ouvrières." Les lieux de mémoire. 3 Les France: vol. 3: De l'archive à l'emblème. Ed. Pierre Nora. Paris: Gallimard, 1992. 87-129.

Perrot, Michelle. Mélancolie ouvrière. Paris: Grasset, 2012.

Pillon, Thierry. "Récits des rêves ouvriers." Communications 89 (2/2011): 193-206.

Pillon, Thierry. Le corps à l'ouvrage. Paris: Stock, coll. "Un ordre d'idées," 2012.

Piton, Monique. C'est possible, le récit de ce que j'ai éprouvé durant cette lutte de Lip. Paris: Editions des femmes, 1975.

Ragon, Michel. Les écrivains du peuple. Paris: Jean Vigneau, 1947.

Ragon, Michel. Histoire de la littérature prolétarienne de langue française. Paris: Albin Michel, 1974.

Richter, Noë. La conversion du mauvais lecteur et la naissance de la lecture publique. Marigné: Editions de la Queue du chat, 1992.

Roche, Agnès. Emile Guillaumin. Un paysan en littérature, Paris: Editions du CNRS, 2006.

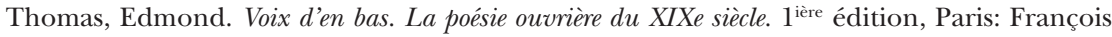
Maspéro, 1979; $2^{\circ}$ édition, Paris: La Découverte, 2002.

Truquin, Norbert. Mémoires et aventures d'un prolétaire à travers la révolution. Paris: François Maspero, 1977.

Verret, Michel. "La scène intellectuelle." In his La culture ouvrière. Saint-Sébastien: ACLCrocus, 1988.

Vigna, Xavier. L'espoir et l'effroi. Luttes d'écritures et luttes de classes en France au XXe siècle. Paris: La Découverte, 2016.

\section{ABOUT THE AUTHOR}

Maître de conférences in contemporary history at Université Clermont Auvergne, and a member of its Centre d'Histoire "Espaces et Cultures" (CHEC), Nathalie Ponsard works on the reconstruction of the militant workers' culture in the second half of the twentieth century, at the intersection of social, cultural and oral history. She is the author of Lectures ouvrières à Saint-Etienne du Rouvray (L'Harmattan, 2007). Researching militant workers' memories, she is also interested in workers' writings through a study of the poetry of one such activist ("To proceed from a political and a trade unionist culture of workers to a literary book 
culture of workers: a militant worker writer or a worker militant writer?," SHARP conference Book Culture from Below, Helsinski, 2010). She is currently completing research on "encounters" (between different social groups, most often in the context of factory conflicts, but also in the context of trade-union commitments, and engagements with cinema and poetry) in the militant milieu of the Puy-de-Dôme department from 1968 to 2000.

\section{NOTES}

1 Maitron.org, site d'histoire sociale: http://biosoc.univ-paris1.fr/. Prosopography: http:// biosoc.univ-paris1.fr/spip.php?article258\&var_recherche=prosopographie.

2 In 1980, some professors and militants, supported by trade-unions (CGT, CFDT and CGT-FO) and 15 town councils, founded le Centre de Documentation du mouvement ouvrier et du travail (CDMOT). It became Le centre d'histoire du travail in 1994. It has a mission: to collect archives of the world of peasants and workers. It has a library focused on social history.

3 This library-museum specializes in contemporary history and international relations. It is linked with Université de Paris Ouest Nanterre la Défense and associated to the Bibliothèque nationale de France.

4 The APA is a non-profit association registered under the French law of 1901. Its main goal is the collection, conservation, and dissemination of unpublished autobiographical texts. See http://autobiographie.sitapa.org/.

5 To which one must add many "workers' testimonies" studied by Eliane Le Port in her thesis Le témoignage écrit ouvrier depuis 1945, under the direction of Nicolas Hatzfeld, Université d'Evry Val d'Essonne, which was defended in December 2017. Le Port studied a corpus of 200 testimonies, published since 1945, written by men and women who had experience of working in the motorcar manufacturing, mining, or iron and steel industries.

6 In 2013, the French Association for Labour History (AFHMT: Association française pour l'histoire des mondes du travail) was created: http://afhmt.hypotheses.org/275.

7 Matériaux pour l'histoire de notre temps. Special issue "Le mouvement ouvrier au miroir de la biographie." Nos. 104-105 (2011).

8 These authors refused introspection. On the contrary, they wanted to leave a testimony for the Others (their children, more often their colleagues) about proletarian conditions and the worker's capacities.

9 Michel Ragon was born in 1924. He was an autodidact and a writer. In Paris he was friendly with Henry Poulaille who had founded a proletarian school of writers to assert independence from the communist world and especially from socialist realism. In 1947, Ragon compiled an anthology of proletarian literature (with a critical study), Les écrivains du peuple.

10 Noë Richter used this term: it refers to a new phase where the reader constructs a rigorous schedule of readings of literary novels, wanting to acquire a classical or legitimate culture. See also the review of Richter's La conversion du mauvais lecteur et la naissance de la lecture publique (Marigné: Ed. de la Queue du chat, 1992) by Philippe Hoch in Bulletin des bibliothèques de France [online], n 4, 1992.

11 This research is based upon more than three hundred texts by or about the French working class. 
12 Factory writings are both writings produced as part of the daily routine of the factory, and sometimes writings which the authors composed while at work in the factory.

13 Journal d'un groupe d'ouvrières, Montpellier 1967-1968, BDIC, FdeltaRes578/14, 65 pages; [Lopez, Aurélie], Aurélie, journal d'une OS [unskilled worker], Editions ouvrières, 1979, 144 pp (diary written between 1970 and 1974); Monique Piton, C'est possible, le récit de ce que j'ai éprouvé durant cette lutte de Lip, Paris: Editions des femmes 1975.

14 Dans un bien-être bien sûr, Lyon, Fédérop, 1975; La Méditerranée traversait la France, Grenoble, Presses universitaires de Grenoble, 1980; Ni Dieu ni Maire. De Charléty aux moutons noirs, Quimperlé, La Digitale, 1989; Tous les chevaux ont couru, Quimperlé, La Digitale, 1989.

15 Nathalie Ponsard, "To proceed from a political and a trade unionist culture of workers to a literary book culture of workers: a militant worker writer or a worker militant writer?," paper presented at Book Culture from Below-the 18th Annual SHARP Conference, Helsinski, 17-20 August 2010.

16 For instance communist training of cadres between Italy and France. See Andréa Pozetta, "Italian Communist Party Schools: Writing Practices and Linguistic Analysis," paper presented at the First conference of the European Labour History Network (ELHN), Turin, 14-16 December 2015.

17 Nathalie Ponsard, "French workers' life-writing and commitments in the European worker movement in the Twentieth century," paper presented at IABA Europe conference Trajectories of (Be)longing: Europe in Life Writing, Tallinn University, Estonia, 18-20 May 2011. 